\title{
HADIS DARI MASA KE MASA (KODIFIKASI HADIS ERA MUTAQADDIMIN)
}

\author{
Fatimah \\ Srikandi Lintas Iman Yogykarta, fatimah.if4@gmail.com
}

Diterima: 23 Desember $2019 \quad$ Direvisi: 12 Juni $2020 \quad$ Diterbitkan: 30 Juni 2020

\begin{abstract}
Hadith as the second Islamic teaching has a significant difference with the Qur'an in terms of official bookekeeping. In terms of the preservation of the Qur'an since the beginning of the Qur'an, there bas been a decree to keep watch over and be protected from falsehood, but not with the Prophet's hadith. As before the reign of Caliph Umar bin Abdul Aziz even the writing or bookkeeping was probibited. But after considering some of the impending advances if the hadith was not made up of books, the false hadiths would have arisen from irresponsible people, the death of the companions who had memorized the war, and dispersed the scholars to various territories with their death. Moreover, hadith memorization has become a tradition among the people and the fear of memorization has decreased. It was from these questions that the caliphate of Umar bin Abdul Aziz raised concerns about the bookkeeping in order to preserve and maintain its legitimacy. The official formulation of the badith dates back to the second century $H$. under the command of Umar bin Abdul Azir. Hadith as a teaching of Islam, produced various books of hadith scholars who were born mutaqaddimin and endowed. However in this article the author will focus more on the development of the books of the hadith in the mutaqaddimin period. The period of mutaqaddimin is the period between I H and the third century $H$, the opening of the hadith of the mutaqaddimin period from the end of the second century $H$ to III H. In this period of mutaqaddimin the books of the hadith were born by the scholars including: first, the century to II H there are many scholars who produce the book of the hadith, among them the most famous is the book of hadith of the priest of Malik called the book of Muwaththa 'Malik. Secondly, in the third century $H$ the books of the badith were born including the Book of Sabih Bukbari, the Book of Muslim Tradition, the Book of Sunan Abu Dawud, the Book of Sunan At-Tirmidri, the Book of Sunan AnNasa'iy, the Book of Sunan Ibn Majah and others. The writing of this journal uses the library research method that the author has obtained from various reading sources related to this research.
\end{abstract}

Keywords: Hadith, Hadith Books, Mutaqaddimin

\begin{abstract}
Abstrak
Hadis sebagai ajaran Islam ke dua memiliki perbedaan yang cukup signifikan dengan Alqu'ran dalam perihal pembukuan secara resmi. Dari segi pemeliharaan sejak awal Alqu'ran diturunkan sudah ada perintah pembukuan agar tetap terjaga dan terpelihara dari kepalsuan, namun tidak dengan hadis Nabi. Sebagaimana sebelum pemerintahan khalifah Umar bin Abdul Aziz bahkan penulisan atau pembukuan hadis dilarang untuk dilakukan. Namun setelah mempertimbangkan beberapa permaslahatan yang akan datang jika hadis tidak dilakukan pembukuan, maka hadis palsu akan banyak bermunculan dari orang-orang yang tidak bertanggung jawab, meninggalnya para sahabat yang hafal hadis dalam perperangan, dan menyebarnya para ulama ke berbagai wilayah diiringi wafatnya mereka. Selain itu sebelumnya hafalan hadis menjadi tradisi dalam kalangan masyarakat dan takutnya semangat hafalan semakin menurun. Dari berbagai persoalan tersebut maka timbul rasa kecemasan khalifah Umar bin Abdul Aziz untuk melakukan pembukuan agar terpelihara dan tetap terjaga keshahihannya. Pembukuan hadis secara resmi dimulai sejak abad ke II $\mathrm{H}$ atas perintah Umar bin Abdul Aziz. Hadis sebagai ajaran Islam, melahirkan beragam kitab hadis yang dilahirkan ulama mutaqaddimin dan mutaakhirin. Namun dalam tulisan ini penulis akan lebih fokus membahas tentang perkembangan kitab-kitab hadis di masa mutaqaddimin.
\end{abstract}


Periode mutaqaddimin merupakan periode yang berada antara tahun I Hijriyah sampai abad III Hijriyah, pembukuan hadis di periode mutaqaddimin di mulai pada akhir abad II H hinngga III H. Pada periode mutaqaddimin ini kitab-kitab hadis yang dilahirkan oleh para ulama diantaranya: pertama, di masa abad ke II H banyak ulama yang melahirkan kitab hadis diantaranya yang paling terkenal adalah kitab hadis karangan Imam Malik yang disebut kitab Muwaththa' Malik. Kedua, di masa abad ke III H kitab-kitab hadis yang dilahirkan diantaranya Kitab Shahih Bukhari, Kitab Shahih Muslim, Kitab Sunan Abu Dawud, Kitab Sunan At-Tirmidzi, Kitab Sunan An-Nasa'iy, Kitab Sunan Ibnu Majah dan lainnya. Penulisan jurnal ini menggunakan metode library research atau kajian kepustakaan yang tentunya diperoleh oleh penulis dari berbagai sumber bacaan yang berkaitan dengan penelitian ini.

Kata Kunci: Hadis, Kitab-kitab Hadis, Mutaqaddimin

\section{PENDAHULUAN}

Hadis secara struktural dan fungsi disepakati oleh kaum muslimin sebagai sumber ajaran Islam kedua setelah Alquran, karena hadislah ajaran Islam menjadi lebih jelas, rinci dan tentunya lebih spesifik. Dalam sejarah perkembangannya, hadis di masa Rasulullah, para sahabat dan tabi'in keberadaan hadis sangatlah dijaga. Di zaman Rasulullah kepandaian para sahabat dalam tulis baca sudah bermunculan, hanya saja sangat terbatas. Karena keterbatasan dalam tulis baca para sahabat saat itu, maka upaya yang dilakukan oleh Rasulullah untuk menjaga hadis yaitu dengan menekankan pada para sahabat untuk menghapal, memahami, memelihara, memantapkan hadis dalam amalan kehidupan sehari-hari, serta menyebarkannya kepada orang lain. Walaupun penulisan hadis secara resmi belum dilakukan, bukan berarti para sahabat ketika itu tidak menuliskan hadis. Sebagian para sahabat, terlepas dari boleh atau tidak bolehnya penulisan atau kodifikasi hadis dilakukan, namun secara individu ada beberapa sahabat yang telah menuliskannya.

Berjalannya waktu, pembukuan hadis menjadi persoalan yang sangat penting dilakukan. Beriringnya meninggalnya para sahabat dalam peperangan, meninggalnya para ulama dan telah meyebar di berbagai wilayah, munculnya hadis palsu menjadi suatu persoalan yang mengkhawatirkan bagi khalifah Umar bin Abdul Aziz. Umar takut hadis akan hilang dan punah jika tidak dilakukan pembukuan. Atas kegelisahan inilah maka atas perintah Umar dan dimasa kepemimpinannya inilah pembukun hadis secara resmi baru dilakukan.

Dari sedikit penjabaran dan persoalan diatas maka dalam makalah ini akan dibahas tentang pembukuan hadis di masa mutaqaddimin. ${ }^{1}$ Mutaqaddimin merupakan gelar yang diberikan kepada ulama-ulama hadis pada abad ke II dn ke III Hijrah. Para mutaqaddimin mengumpulkan hadis dengan usaha sendiri dan pemeriksaan sendiri dengan cara menemui para penghapal hadis menuju berbagai pelosok negeri. Dari penjabaran di atas maka penulis ingin menjelaskan bagaimana pembukuan awal masa mutaqaddimin, Bagaimana model pencarian hadis dan pembukuan dalam tradisi dan mengapa hal tersebut terjadi, Bagaimana transformasi pembukuan hadis tersebut dalam pembukuan berikutnya. Dari tulisan ini mungkin kita bisa mengambil hikmah dari pembelajaran sejarah masa lalu tentang usaha ulama hadis untuk melakukan usaha penghimpunan pembukuan hadis. Usaha yang dilakukan oleh para ulama hadis terdahulu tidak begitu mudah bahkan ada yang berjuang untuk mengumpulkna hadis

1 Masa mutaqaddimin juga dikenal sebagai periode tabi'in dan tabi' tabi'in dimana periode ini berada pada abad II hingga ke III H. Pada abad keIII H merupakan masa kejayaan penghimpunan hadis karena pada masa itu kegiatan pengkodifikaian atau pembukuan hadis mengalami perkembangan yang luar biasa, bahkan disebut sebagai puncaknya perkembangan pembukuan hadis. Lihat, Muhammad Ali, "TEORI KLASIFIKASI KITAB HADIS," Tabdis: Jurnal Kajian Ilmu Hadis 8, no. 2 (2019): 159-60. 
dalam waktu 16 tahun sehingga kitabnyapun bisa kita lihat dan pelajari hingga kini seperti kitab Shahih Bukhari yang termasyhur hingga saat ini.

\section{LITERARUR REVIEW}

Pembahasan hadis, khususnya tentang pembukuan hadis telah mengundang banyak peminat untuk melakukan penelitian. Namun penelitian khusus yang terkait dengan tulisan yang penulis buat ini belum ada yang melakukannya. Berikut merupakan hasil kajian literatur terdahulu yang berkaitan dengan tulisan penulis, diantaranya:

\section{Periodesasi Perkembangan Studi Hadis}

(Dari Tradisi Lisan/Tulisan Hingga berbasis Digital), ditulis oleh Luthfi Maulana. Jurnal tersebut ditulis oleh Luthfi Maulana dibahas tentang sejarah atau perkembangan kajian hadis yang sangat signifikan. Sejarah perkembangan hadis yang ditulis tersebut dimulai dari tradisi lisan, hafalan, kritik matan, kritik sanad, hingga di era digital ini. Penulisan dan pembukuan hadis tersebut dilakukan karena khawatirnya akan hilangnya hadi Nabi. Jika dilihat dari segi kelemahannya, jurnal ini ditulis begitu terlalu general dan tidak fokus pada satu pembahasan atau permasalahan melainkan langsung pada tiga pembahasan yang mana memiliki masa yang berbeda pula. ${ }^{2}$

Perkembanagan Literarur Hadis Pada Masa Awal Islam, ditulis oleh M. Jayadi. Jurnal yang ditulis oleh M. Jayadi ditulis dengan informasi yang cukup lengkap mulai dari pro dan kontra tentang dibolehkan atau tidak dibolehkan menulis hadis Nabi hingga perkembangan literarur hadis dari abad I hingga abad ke III H. Namun, jika dilihat dari sisi kelemahannya dalam penulisan abstrak tidak dituliskan bagaimana hasil penelitiannya atau

2 Luthfi Maulana, "Periodesasi Perkembangan Studi Hadits (Dari Tradisi Lisan/Tulisan Hingga Berbasis Digital)," ESENSIA: Jurnal Ilmu-Imu Ushuluddin 17, no. 1 (2016): 111-23. perkembangan literatur hadis itu senidiri kurang tergambarkan. ${ }^{3}$

Sistemasi Kodifikasi Hadis Nabi Dari Tinjauan Sejarah, ditulis oleh Masturi Irham. Jurnal yang ditulis oleh Masturi Irham dengan jelas menerangkan tentang sejarah penulisan hadis mulai dari masa nabi yang terdapat pro dan kontra tentang boleh atau tidak bolehnya ditulis hadis, penulisan hadis dari masa Nabi, masa sahabat, masa hingga tabi'in. Namun, jika dilihat dari sisi kelemahannya tulisan ini tidak menerangkan perbedaan sistem penulisan atau pengkodifikasian hadis yang ditulis oleh para sahabat dan tabi'in. ${ }^{4}$

\section{METODE PENELITIAN}

Metode yang penulis gunakan dalam penelitian ini adalah metode library research atau dikenal sebagai metode kepustakaan dengan cara membaca literatur yang berkaitan dengan penelitian hadis, khususnya tentang kitab-kitab hadis pada masa mutaqaddimin. Selain itu, dalam penelitian ini penulis juga menggunakan pendekatan deskriptif-historis atau menggambarkan tentang peristiwa yang terjadi di masa lampau terkhusus tentang kitab-kitab hadis yang terpopuler di masa mutaqaddimin.

\section{SEJARAH SINGKAT KODIFIKASI HADIS}

Berdasarkan data sejarah, secara resmi dan publik kegiatan kodifikasi hadis dimulai pada abad II H di masa pemerintahan khalifah Umar bin Abdul Aziz ${ }^{5}$ (99-101 H), khalifah ke

3 M Jayadi, "Perkembangan Literatur Hadis Pada Masa Awal Islam," Khizanah Al-Hikmah: Jurnal Ilmu Perpustakaan, Informasi, Dan Kearsipan 3, no. 1 (2015): 65.

${ }^{4}$ Masturi Irham, "Sistematika Kodifikasi Hadis Nabi Dari Tinjauan Sejarah," Addin 7, no. 2 (2013): 54323.

5 Abu Hafsh Umar bin Abdul Aziz bin Marwan bin al-Hakam bin Abil Ash Umayah bin Abdi Syams bin Abdi Manaf bin Qushai bin Kilab merupakan nama lengkap Umar bin Abdul Aziz. Sebagaimana ia lahir pada tahun $61 \mathrm{H}$ dan wafatnya pada tahun $101 \mathrm{H}$. Umar dikenal sebagai seorang pemimpin yang mencintai hadis-hadis Nabi dan beliaupun sering menghadiri majlisnya Abu Hurairah dan sahabat-sahabat lainnya. 
delapan Bani Umayah, atau zaman ini disebut dengan periode tabi'in. Di dalam bahasa Arab, kata kodifikasi dikenal dengan al-tadwin, yang berarti mengumpulkan dan menyusun. Kegiatan kodifikasi hadis Nabi diperintahkan oleh Umar bin Abdul Aziz melibatkan beberapa ahli dalam perihal ini, bukan secara perorangan. Dengan kata lain kodifikasi hadis dilakukan bukan inisiatif perorangan dan bukan untuk keperluan sendiri, tetapi karena perintah resmi dari khalifah. ${ }^{6}$

Kodifikasi hadis yang dilakukan atau yang diperintahkan oleh Umar bin Abdul Aziz dilatarbelakangi oleh kekhawatirannya terhadap berbagai persoalan yang terjadi selama pemerintahannya. $^{7}$ Kekhawatiran yang dirasakan itu berdasarkan pada tiga hal, diantaranya: pertama, takutnya terjadinya kehilangan dan kepunahan hadis seiring banyaknya para ulama telah tersebar ke berbagai negeri dan wafatnya mereka. Kedua, bermunculan hadis-hadis palsu dan munculnya bid'ah dari orang yang tidak bertanggung jawab, sehingga bercampurnya hadis yang palsu dan hadis yang shahih. Ketiga, Semakin meluasnya daerah kekuasaan Islam, sementara itu kemampuan para tabi'in antara saatu

Lebih lengkapnya lihat, Saifuddin Zuhri Qudsy, "Umar Bin Abdul Aziz Dan Semangat Penulisan Hadis," ESENSLA: Jurnal Ilmu-Imu Ushuluddin 14, no. 2 (2013): 260.

6 Idri, Studi hadis (Jakarta: Kencana Prenada Media Group, 2010), 93.

${ }^{7}$ Sebelum pemerintahan Usman tepatnya pada periode ke tiga dan sedang berlangsungya pemerintahannya penyebaran hadis sudah dilakukan diberbagai wilayah diantaranya di Mesir, Syam, Irak, Samarkand hingga meluas ke Spanyol pada tahun $93 \mathrm{H}$. Hal tersebut seiring berangkatnya para sahabat yang hafal hadis ke daerah tersebut dalam tugas memangku tugas jabatan dan menyebarkan hadis Nabi. Pada periode ketiga tersebut munculnya usaha orang tak bertanggung jawab untuk memalsukan hadis Nabi. Perihal ini terjadi setelah wafatnya khalifah Ali bin Abi Thalib sebagaimana terpecahnya umat Islam ke dalam beberapa golongan atau kelompok. Golongan itu diantaranya adalah golongan syiah, khawarij, dan jumhur. Lihat, Agusman Damanik, "URGENSI STUDI HADIS DI UIN SUMATERA UTARA," SHAHIH Jurnal Kewabyuan Islam) 1, no. 1 (2018): 88. dengan yang lainnya berbeda. ${ }^{8}$

Perintah kodifikasi hadis dilakukan oleh Umar bin Abdul Aziz ${ }^{9}$ dengan memberitahu seluruh pejabat dan para ulama di berbagai daerah untuk menghimpun hadishadis yang tersebar di masing-masing daerah melalui surat perintah. Surat tersebut dikirim kepada gubernur Madinah, Abu Bakr ibn Muhammad ibn 'Amr ibn Hasmin' (w. 117 H). Imam Muhammad Ibn Muslim Ibn Syihab al-Zuhri, seorang ulama besar yang ahli di bidang fiqih dan hadis di negeri Hijaz dan Syam juga dikirimi surat serupa. Sebelum khalifah meninggal, Al-Zuhri sebagai ulama yang menuliskan kitab hadis atas anjuran khalifah telah berhasil melaksanakan tugasnya. Kompilasi hadis yang dilakukan oleh Al-Zuhri dikirim ke berbagai daerah untuk penghimpunan hadis selanjutnya. ${ }^{11}$

8 Octoberinsyah and kawan-kawan, Al-Hadis (Yogyakarta: Pokja Akademik UIN Sunan Kalijaga, 2005), 43

9 Dari beberapa persoalan yang muncul yang diakibatkan oleh pergolakan politik yang sudah cukup lama, maka Umar bin Abdul Aziz segera mengambil tindakan guna menyelamatkan hadis dari kemusnahan dan pemalsuan. Umar bin Abdul Azizidikenal sebagai khalifah yang berakhlak mulia, adil dan wira'i. Menurut beberapa riwaya, Umar ikut terlibat mendiskusikan hadis-hadis yang dihimpun. Lihat, Munazier Suparta, Ilmu Hadis (Jakarta: Rajawali Pers, 2011), 91.

$10 \mathrm{Abu}$ Bakr ibn Muhammad ibn 'Amr ibn Hasmin seorang Gubernur Madinah, guru dari Ma'mar. Al-Laits, Al-Auza'y, Malik, Ibnu Ishaq dan Ibnu Abi Dzi'bin, diminta oleh Umar bin Abdul Aziz supaya membukukan hadis Nabi yang terdapat pada penghapal wanita yang terkenal, Amrah binti Abd ar-Rahman ibn Sa;ad ibn Zurarah ibn Ades, seorang ahli fiqh, murid Aisyah, dan hadis-hadis yang ada padaAl-Qasim ibn Muhammad ibn Abi Bakr ash-Shiddiq $(107 \mathrm{H})$, seorang pemuka tabi'in dan salah seorang fuqaha tujuh Madinah. Selain itu perintah pembukuan hadis juga dikirimi surat oleh khalifah kepada semua gubernur di wilayah kekuasaan. Lihat, Teungku Muhammad Hasbi AshShiddieqy, Sejarah Dan Pengantar Imu Hadis (Semarang: Pustaka Rizki Putra, 2009), 53.

11 Saifuddin, Arus TradisiTadwin Hadis dan Historisgrafi Islam (Yogyakarta: Pustaka Pelajar, 2011), 144. Lihat, Sandi Santosa, "Melacak Jejak Pensyarahan Kitab Hadisll ," Diroyab: Jurnal Ilmu Hadis 1, no. 1 (2016): 81. 
Surat yang ditulis oleh Umar bin Abdul Aziz kepada gubernur Madinah dan pemimpin di berbagai wilayah yang isinya sebagai berikut:

Perikssalah mana saja yang termasuk hadis Rasulullh SAW. Lalu tulislah, karena sesunggubnya saya khawatir terbadap musnabnya ilmu dan wafatnya para ulama, dan janganlah terima kecuali hadis Nabi $S A W$. Dan hendaklah kalian sebarkan ilmu dan adakanlah majelis, sehingga orang yang tidak tahu dapat diajarkan. Karena seseunggubnya ilmu itu tak akan binasa sehingga ia menjadi rahasia. ${ }^{12}$

Setelah pemberitahuan penghimpunan hadis secara resmi boleh dilakukan, para ulama dengan semangat berlomba-lomba untuk melakukan pembukuan hadis atas anjuran Abu 'Abbas As-Saffah dan anak-anak dari khalifah -khalifah Abbasiyah. Namun secara pasti, setelah pembukuan hadis dilakukan oleh $\mathrm{Al}$ Zuhri, tidak diketahui siapa saja ulama-ulama yang mula-mula melakukan pembukuan hadis, karena ulama-ulama yang datang setelah AlZuhri hidup pada satu zaman. ${ }^{13}$

Ulama-ulama yang bekerja keras untuk melakukan kodifikasi setelah Al-Zuhri diantaranya adalah Ibnu Juraij $(80-150 \mathrm{H})$ di Makkah, Muhammad ibn Ishaq (w. $151 \mathrm{H}$ ) di Madinah, Ibn Abi Dzi'bin (80-158 H) di Madinah, Malik Ibn Anas (93-179 H) di Madinah, al-Rabi' ibn Shabih (w. 160 H) di Bashrah, Hammad Ibn Salamah (w. 176 H) di Bashrah, Sa'id ibn Abi Arubah $(156 \mathrm{H})$ di Bashrah, Sufyan al-Tsaury $(97-161 \quad \mathrm{H})$ di Kufah, al-Auza'iy (88-157 H) di Syam, Ma'mar ibn Rasyid (93-153 H) di Yaman, Ibn Mubarak (118-181 H) di Khurasan, Abdullah ibn Wahhab (125-197 H) di Mesir, Jarir ibn Abd al-Hamid (110-188 H) di Roy. Ulama-ulama yang disebutkan merupakan tokoh hadis yang sangat terkenal dalam sejarah pembukuan

12 Hading Hading, "Sejarah Pertumbuhan Dan Perkembangan Hadis," Shaut al Arabiyyah 4, no. 2 (2016): 15.

13 Agus Solahuddin and Agus Suryadi, Ulumul Hadis (Bandung: Pustaka Setia, 2009), 40. hadis di zamannya. Sayangnya kitab-kitab yang mereka tulis tidak sampai ke tangan generasi sekarang. ${ }^{14}$

\section{SISTEM ULAMA ABAD KE II H MEMBUKUKAN HADIS}

Mulai pada periode atba' al-tabi'in, sejarah kompilasi dan kodifikasi hadis memasuki tahap yang sangat penting dalam perkembangannya. Tidak seperti tadwin hadis sebelumnnya yang umumnya dilakukan secara acak tanpa melakukan upaya klasifikasi dan sistematisasi. Namun, di lain sisi ulama melakukan pembukuan hadis di masa ini tanpa penyaringan. Mereka mencampurkan fatwafatwa sahabat dan tabi'in serta hadis Nabi. Itulah sebabnya kitab-kitab hadis yang ditulis di masa ini terdapat hadis marfu', mauquf, dan maqthu'.

Pada periode ini, khususnya sejak pertengahan abad ke II $\mathrm{H}$, telah mulai dilakukan kompilasi dan kodifikasi hadis secara sistematis berdasarkan bab-bab atau subjeksubjek tertentu (tashrif). Sepanjang periode atba' al-tabi'in, secara umum terdapat ciri-ciri tadwin hadis di antaranya adalah: (a) hadis disusun secara teratur dan sistematis berdasarkan bab-bab atau subjek-subjek tertentu; (b) kompilasi hadis-hadis yang ditulis menggabungkan hadis Nabi saw, pendapat sahabat, dan fatwa tabi'in. Berbeda dengan sahifah-sahifah sebelumnya yang hanya mengumpulkan hadis Nabi saja; (c) hadis-hadis yang dikumpulkan saling berkaitan dalam satu bab, kemudian bab-bab tersebut digabungkan dengan bab-bab lainnya dalam satu kitab; (d) materi-materi hadis yang mengisi karya-karya kompilasi hadis dihimpun dari shahifahshahifah (shubuf) dan buku-buku kecil (kararis) yang ditulis pad aperiode sahabat dan tabiin, serta apa yang dinukil, baik itu berupa

14 Octoberinsyah and kawan-kawan, Al-Hadis, 44 
pendapat sahabat maupun fatwa dari tabiin. ${ }^{15}$

Kompilasi hadis yang ditulis pada periode ini mempunyai judul yang sangat beragam, diantaranya: muwatha', mushnaf, jami ${ }^{16}$, sunan $^{17}$, dan musnad ${ }^{18}$. Selain itu juga ada menggunakan judul yang lebih khusus, seperti jihad, zuhd, maghaziy, sirah dan lainnya. ${ }^{19}$ Kitabkitab hadis yang dikumpulkan dan dibukukan pada abad ini jumlahnya cukup banyak. Namun, yang paling terkenal di kalangan hadis adalah: al-Muwaththa ${ }^{20}$ disusun oleh Imam

15 Saifuddin, Arus Tradisi Tadwin Hadis dan Historisgrafi Islam, 149.

16 Kitab jami' merupakan penghimpunan hadis nabi yang di dalamnya disusun berdasarkan bab yang berisi dengan berbagai tema tertentu. Temanya biasanya terdiri dari 8 bab tentang: adab sopan santun, hukum, aqidah, tafsir, bermufasir, tanda-tanda kiamat, sifat-sifat kebaikan dan tanda-tanda hari kiamat. Kitab tergolong jami' diantaranya Jami' Shabih Bukhari, Jami' Shabih Muslim. Lihat, Ismail Yusuf, "SEJARAH PERKEMBANGAN HADIS DAN METODOLOGINYA PADA ABAD III HIJRIAH," AL $A S A S$ 1, no. 2 (2018): 110.

17 Kitab sunan merupakan kitab hadis yang mana penyusunan bab-nya berdasarkan bab-bab fiqih dan kualitas tidaklah hadis mauquf, kecuali hadis hasan dan shahih. Metodologi penyususnan hadisnya tidak berdasarkan tema umum melainkan terdiri dari materi yang bersangkutan dengan masalah hukum fiqih. Sebagaimana kitab sunan yang terkenal diantaranya diantaranya Sunan Tirmizi, Sunan Ibnu Majah, Sunan Abu Dawud, dan Sunan An-Nasai. Lihat, Ibid.

${ }^{18 K i t a b}$ musnad merupakan kitab yang penyusunannya disusun oleh nama sahabat yang besangkutan, seperti Musnad Imam Ahmad bin Hambal. Hadis-hadis yang terdapat dalam kitab musnad disusun secara acak dalam satu bab yang mana di dalamnya terdapat berbagai macam tema. Di dalamnya hadis tentang puasa bercampur dengan hadis tentang sholat. Hadis yang disusun dalam kitab musnad tidak berdasarkan tema, namun berdasarkan nama perawinya. Selain itu di dalam kitab musnad, hadis shabih dan hadis dhaif juga bercampur. Lihat, Ibid., 109.

19 Saifuddin, Arus Tradisi Tadwin Hadis dan Historisgrafi Islam, 150.

20 Kitab al-Muwaththa' disusun oleh Imam Malik dengan mengumpulkan hadis dari 900 orang Syaikh. Hadis yang dikumpulkan diseleksi dulu agar tidak terjadi pengulangan sehingga yng tersissa beberapa ribu hadis saja. Kegiatan pembukuan hadis ini dilakukannya dalam waktu 40 tahun. Ia sangat banyak melakukan revisi terhadap karyanya, sehingga muncul alMuwaththa' dalam benyak versi (naskah). Penyusunan kitab ini dikelompokkan berdasarkan bab-bab fiqih. Yang mana di dalamnya terdapat 61 subyek bahasan.
Malik $^{21}$ (95 H-179 H), al-Maghaziwal Siyar disusun oleh Muhammad Ibn Ishaq $(150 \mathrm{H})$, al-Jami' disusun oleh Abdul Razzaq As-San'any $(211 \mathrm{H})$, al-Mushannaf disusun oleh Sy'bah Ibn Hajjaj $(160 \mathrm{H})$, al-Mushannaf disusun oleh alLaits Ibn Sa'ad $(175 \mathrm{H})$, al-Mushannaf disusun oleh al-Auza'i $(150 \mathrm{H})$, al-Mushannaf disusun oleh al-Humaidy (219 H), al-Maghazin Nabawiyah disusun oleh Muhammad Ibn Waqid Al-Aslamy, al-Musnad disusun oleh Abu Hanifah $(150 \mathrm{H})$, al-Musnad disusun oleh Zaid Ibn Ali, al-Musnad disusun oleh Imam AsSyafi'i $(204 \mathrm{H})$, dan Muktalif Al-Hadis disusun oleh Imam Asy-Syafi'i. ${ }^{22}$

Pada periode atba al-tabi'in atau abad

ke II $\mathrm{H}$, tokoh-tokoh yang termayhur diantaranya adalah Imam Malik, Ibnu Ishaq,Yahya ibn Sa'id Al-Qaththan, Waki Ibnu Al-Jarrah, Sufyan Ats Tsuri, Ibnu Uyainah, Syu'bah Ibnu Hajjaj, Abdul ArRahman ibn Mahdi, Al-Auza'i, Al-Laits, Abu Hanifah $^{23}$, dan Asy-Syafi'i. ${ }^{24}$

Adapun kitab yang ditulis oleh Imam Malik yaitu al-Muwaththa ${ }^{25}$, dinilai oleh para

Lihat, Ummi Sumbullah, Studi 9 Kitab Hadis Sunni (Malang: UIN Malik Press, 2013), 47.

${ }^{21}$ Nama lengkap Imam Malik adalah Malik bin Anas 'Amiri bin Amar bin Gaiman bin Khasyai bin 'Amar lahir di Madinah. Ia selain dikenal sebagai imam Mazhab fiqih juga sangat populer di bidang hadis, bahkan diberi gelar sebagai amin al-hadis seperti tokoh lainnya. Lihat, Muhammad Alfatih Suryadilaga and kawan-kawan, Ulumul Hadis (Yogyakarta: Kalimedia, 2015), 192.

22 Solahuddin and Suryadi, Ulumul Hadis, 41.

${ }^{23} \mathrm{Abu}$ Hanifah nama lengkapnya adalah anNu'man bin Tsabit bin Zutah, bekas sahaya Taimullah bin Sa'labah al-Kufi. Ia lahir di Kuffah pada tahun 80 H/699 M dan wafat pada tahun $150 \mathrm{H} / 767 \mathrm{M}$. Abu Hanifah lebih dikenal sebagai salah seorang dari empat serangkai Imam mazhab fiqih ketimbang muhaddits (ahli hadis). Diantara hadis-hadis yang dihimpuan Abu Hanifah dihimpun menjadi musnad. Banyak periwayatan hadis yang dilakukan oleh Abu Hanifah, baik yang berbentuk musnad maupun yang lainnya. Lihat, Suryadilaga and kawan-kawan, Ulumul Hadis, 188.

${ }^{24}$ Solahuddin and Suryadi, Ulumul Hadis, 42.

25 Derajat hadis-hadis yang terdapat dalam alMuwaththta' berbeda-beda, diantaranya ada hadis shahih, hadis hasan, dan hadis dha'if. Menurut Ibn Hazm dalam al-Muwaththa' ada hadis-hadis yang dilemahkan oleh 
ulama sebagai kitab kodifikasi hadis yang pertama dan diwariskan hingga sekarang. Kitab ini isinya memuat 1726 riwayat yang sumbernya berasal dari Nabi saw, sahabat dan tabi'in. ${ }^{26}$

Kitab al-Muwaththa ${ }^{27}$ di disusun semenjak tahun $143 \mathrm{H}$, bertepatan di masa kepemimpinan khalifah al-Manshur yaitu salah seorang khalifah dari Bani 'Abbasiyah. Muridnya Imam al-Syafi'i memberikan pujiannya terhadap gurunya dengan menyebutkan bahwa Muwaththa' Malik merupakan kitab shabih setelah Alquran.

\section{LAHIRNYA KITAB-KITAB HADIS UTAMA}

Telah dibahas sebelumnya, bahwa pada abad ke II H, antara hadis Nabi dan pendapatpendapat sahabat dan fatwa-fatwa tabi'in tidak dipisahkan. Di abad ke III ${ }^{28}$ keadaan seperti itulah yang diperbaiki oleh para ulama hadis. Pada periode ini disebut juga sebagai periode Atba' Atba' al-Tabi'in, proses kompilasi dan kodifikasi hadis disusun secara sistematis berdasarkan bab-bab. Jika dibandingkankan dengan periode sebelumnya, tadwin hadis di

Jumhur yang membahas isi kandungannya. Namun jika dilihat dari segi penulisannya, maka semua isinya dipandanng shahih sehingga dapat dijadikan bujjah. Lihat, Ash-Shiddieqy, Sejarah Dan Pengantar Ilmu Hadis, 56.

44.

26 Octoberinsyah and kawan-kawan, Al-Hadis,

27 Al-Muwaththa' merupakan kitab hadis yang terpopuler sekaligus mewakili fase penghimpunan hadis Nabi di masa awal. Sebagaimana isinya dapat mengantarkan kita untuk bagaimana bisa memahami istilah dari sunnah, amal, tradisi, serta hadis yang dapat dijadikan rujukan terutama tentang kehidupan atau tentang hukum dalam Islam. Lihat, Yusran Yusran, "KODIFIKASI HADIS SEJAK MASA AWAL ISLAM HINGGA TERBITNYA KITAB AL-MUWATTHA'," Tabdis: Jurnal Kajian Ilmu Hadis 8, no. 2 (2019): 175.

28 Dalam abad ke III $\mathrm{H}$ usaha pembukuan hadis memuncak. Sesudah kitab-kitab Ibnu Juraij dan alMuwaththta' Imam Malik tersebar dan disambut gembira oleh masyarakat, maka timbullah kemauan menghafal hadis, mengumpulkan dan membukukannya. Selain itu ahli-ahli ilmu berpindah dari sebuah negeri ke negeri lain untuk mencari hadis. Lihat, Ash-Shiddieqy, Sejarab Dan Pengantar Ilmu Hadis, 60. periode atba' atba' al-Tabi'in mengalami perkembangan dan merupakan puncak dari usaha pembukuan hadis.

Masa awal hingga penghujung abad ke III $\mathrm{H}$, pembukuan hadis yang dilakukan sangat selektif sekali, seperti adanya usaha penyaringan, pemeliharaan dan pelengkapan. Pembukuan hadis di masa ini tidak seperti pembukuan hadis sebelumnya, di abad ke III telah ada upaya penyaringan dari hadis yang bukan berasal dari Nabi atau disebut dengan hadis palsu. ${ }^{29}$

Ciri-ciri yang menandai proses tadwin pada periode ini diantaranya: (a) melakukan pemilahan dan pemisahan antara hadis nabi dengan pendapat-pendapat sahabat dan fatwafatwa tabi'in; (b) sudah adanya perhatiaan untuk memberikan penjelasan tentang derajat hadis sahih dari segi kesahihan dan kedaifannya dan tidak mencampur adukkannya; (c) karyakarya hadis yang ditulis menggunakan judul: shabih ${ }^{30}$, sunan $^{31}$, musnad $^{32}$, mukbtalif al-hadits dan lainnya. Selain itu, judul dari kitab-kitab juga menggunakan judul yang lebih khusus seperti maghariy, misalkan al-Maghaziy Ibn Abi Syaibah. ${ }^{33}$

Ulama-ulama

sebelumnya megumpulkan hadis yang hanya terdapat di kotanya masing-masing. Hanya sedikit yang pergi ke kota lain untuk keperluan

29 Muhammad Alfatih Suryadilaga, Aplikasi Penelitian Hadis Dari Teks ke Kontes (Yogyakarta: Kalimedia, 2016), 7. Lihat, Lukman Zain, "Sejarah Hadis Pada Masa Permulaan Dan Penghimpunannya," Diya Al-Afkar: Jurnal Studi al-Quran Dan al-Hadis 2, no. 01 (2014): 23-25.

30 Kitab-kitab Shahih adalah kitab yang di dalamnya hanya terdapat hadis-hadis shahih saja.

${ }^{31}$ Kitab-kitab sunan, (kecuali Sunan Ibn Majah) adalah kitab-kitab yang ditulis tidak memasukkan hadis yang munkar. Adapun hadis dhaif yang tidak munkar dan tidak sangat lemah, terdapat juga di dalamnya, dan kebanyakan diterangkan kedhaifannya oleh penulisnya sendiri. Lantaran ini, derajat kitab sunan berada di bawah kitab shahih. Lihat, Ash-Shiddieqy, Sejarah Dan Pengantar Imu Hadis, 70.

32 Ibid.

33 Saifuddin, Arus Tradisi Tadwin Hadis dan Historisgrafi Islam, 157. 
mengumpulkan hadis. Kondisi seperti ini diubah oleh Al-Bukhari. Beliaulah pencetus untuk meluaskan daerah-daerah yang dikunjungi dalam pencarian hadis. Daerahdaerahh yang beliau kunjungi untuk mencari hadis adalah Maru, Naisabur, Rei, Baghdad, Bashrah, Kaufah, Mekah, Madinah, Mesir, Damsyik, Qusariyah, 'Asqalani, dan Hims. Usaha yang dilakukan oleh Imam Bukhari pergi mengunjungi daerah-daerah lain untuk mengumpulkan hadis demi menyiapkan kitab Shabih-nya yang berjalan selama enam belas tahun. ${ }^{34}$

Para ulama hadis pada sebelumnya secara umum menerima hadis dari perawi lalu menuliskannya langsung ke kitab, tanpa melihat sahih atau tidaknya suatu hadis. Setelah terjadinya pemalsuan hadis dan adanya upaya dari orang-orang zindiq untuk mengacaukan kebenaran hadis dari Nabi, para ulamapun melakukan penyaringan dan penyeleksian terhadap hadis. Kegiatan penyeleksian hadis ini dilakukan sekitar tahun 201-300, tepatnya di zaman Bani 'Abbasyiyah, yakni di masa pemerintahan al-Ma'mun hingga al-Muktadir. Usaha yang dilakukan oleh para ulama untuk menghindari kehadiran hadis palsu yaitu membahas keadaan para perawi dari segi keadilan, tempat kediaman, masa dan lainnya. Selain itu usaha yang dilakukan adalah memisahkan hadis-hadis yang shabih ${ }^{35}$ dari hadis yang dha'if (lemah) yakni dengan mentasbih-kan hadis dan juga memisahkan hadis Nabi dengan fatwa para sahabat dan tabi'in. ${ }^{36}$

Kegiatan penyaringan hadis dan membedakan hadis palsu dan yang lemah pada mulanya dilakukan oleh Ishaq ibn Rahawaih, seorang imam hadis yang sangat termasyhur.

34 Solahuddin and Suryadi, Ulumul Hadis, 42.

35 Para ulama berpendapat bhawa hadis shahih merupakan hadis yang sanadnya bersambung (sampai kepada Nabi Muhammad), diriwayatkan oleh periwayat yang 'adil dan dhabit sampai sanad yang terakhir, dilain itu hadisnya tidak terdapat kejanggalan (syadz) dan cacat (illat). Suryadilaga and kawan-kawan, Ulumul Hadis, 244.

36 Solahuddin and Suryadi, Ulumul Hadis, 43.
Pekerjaan yang mulia ini dilanjutkan dan disempurnakan oleh Imam Bukhari ${ }^{37}$ (w. 256 H) dengan kitabnya yang dikenal Shahih Bukhari ${ }^{38}$. Kemudian, usaha Imam Bukhari ini dilanjutkan oleh muridnya yang tak lain adalah seorang ulama yang sangat alim, yaitu Imam Muslim $^{39}$ (w. $261 \mathrm{H}$ ) dengan kitabnya Shabih Muslim. $^{40}$

Usaha penyaringan hadis yang dilakukan oleh Bukhari dan Muslim ini dilanjutkan oleh pengikutnya hingga berhasil disusun diantaranya Sunan Abu Dawud ${ }^{41}$ (w.

37 Nama lengkap dari Imam Bukhari adalah Abu Abdullah Muhammad Ibnu Ibrahim al-Mughirah al-Bukhari yang lahir di Bukhara pada 13 Syawal $194 \mathrm{H} /$ $816 \mathrm{M}$ dan wafat pada tahun $256 \mathrm{H}$. Lihat, Naila Farah, "Mengenal Kitab-Kitab Hadis," Diya Al-Afkar: Jurnal Studi al-Quran Dan al-Hadis 2, no. 01 (2014): 28.

38 Shahih Bukhari merupakan kitab induk hadis yang utama. Kitab Shahih disusun oleh Bukhari selama 16 tahun dan beliau menamai kitabnya dengan Al-Jami' ash-Shahih al-Musnad min Haditsi Rasul saw. Sebagaimana jumlah isianya adalah 9.082 buah hadis marfu' dan sejumlah hadis mauquf dan maqthu'. Ibnu menetapkan bahwa jumlah hadis yang dibukukan oleh Bukhari ada 7.275 hadis dengan berulang-rulang. Jika tidak diulang-ulang ada 4.000 hadis. Lihat, AshShiddieqy, Sejarah Dan Pengantar Ilmu Hadis, 72.

39 Shabih Muslim merupakan kitab sahih kedua yang menjadi pegangan setelah kitab Shahih Bukhari. Susunan Shahih Muslim lebih baik daripada Shahih Bukhari. Imam Muslim menempatkan hadis tentang wudhu umpamanya di bagian wudhu, tidak tersebar layaknya hadis Shahih Bukhari. Isi kitab Shahih Muslim ini sejumlah 7.275 buah dengan berulang-ulang. Kitabkitab syarahnya juga banyak dainatarnya ada 15 buah. Lihat, Ibid., 73.

40 Solahuddin and Suryadi, Ulumul Hadis, 43.

41 Al-Kaththaby menyatakan dalam kitabya Ma’alim as-Sunan, " ketahuilah bahwa Sunan Abu Daud itu adalah sebuah kitab yang sukar ada tandingannya dalam masalah agama, yang telah diterima baik oleh seluruh umat Islam." Abu Daud sendiri ia mengatakan bahwa, "Aku telah menulis hadis Rasul sebanyak 500.000 hadis, kemudian aku pilih sejumlah 4.800 lalu aku masukkan ke dalam kitab ini. Hadis yang amat lemah yang tidak sah sanad-nya aku terangkan di akhirnya. Tidak kusebutkan dalam kitab ini hadis-hadis yan ditolak oleh seluruh orang. Dan yang tidak aku beri komentar apa-apa berarti hadis yang baik." Suan Abu Daud berisi hadis tentang hukum, sedikt yang beruhubungan dengan urusan lain. Lihat, Ash-Shiddieqy, Sejarah Dan Pengantar Ilmu Hadis, 75. 
275 H), Sunan At-Tirmidzi ${ }^{42}$ (w. 279 H), dan Sunan An-Nasa'iy ${ }^{43}$ (w. 303 H). Sehingga kitabkitab itu kemudian dikenal dikalangan masyarakat dengan judul Al-Ushul Al-Khamsyah. Selain itu Ibnu Majah (w. $273 \mathrm{H}$ ) juga menyusun kitabnya yang disebut Sunan Ibnu Majah. Bagi para ulama, kitab Sunan ini digolongkan ke dalam kitab-kitab induk sehingga kitab-kitab induk yang ada menjadi enam buah, yang mana kita kenal hingga sampai sekarang ini dengan nama Al-Kutub AlSittab. $^{44}$ Lebih lanjutnya lagi kitab Musnad Ahmad, ditempatkan oleh para ulama dibawah kitab yang enam. ${ }^{45}$ Di lain sisi ada yang menyebutkan bahwa kitab pokok yang dimasukkan oleh ulama pada kitab ke enam adalah al-Muwaththa ${ }^{\sharp 6}$ yang disusun oleh Imam

${ }^{42}$ Sunan At-Tirmidzi ditulis oleh At-Tirmidzi dengan mnerangkan yang shahih dan juga mencatat mana yang diamalkan dan mana yang ditinggalkan. Kitab Sunan At-Tarmidzi memiliki faedah yang besar, tinggi derajatnya dan isinya jarang yang diulang-ulang. Sebagian syarahnya adalah Syarh as-Sayuthy dan Syarh as-Sindy. Syarah yang paling besar adalah Aridhah al-Ahwadzy karaya Ibnu Araby al-Maliky, dan sebagian dari muktasarnya ialah al-Muktashar al-Jami' karya Najmuddin Ibn Aqil. Lihat, Ibid.

43 Kitab Sunan An-Nasa'i diberi nama AlMujtaba' min an-Sunan (suanan-sunan pilihan). Awalnya Isi dari kitab sunannya ada yang shahih, ada yang hasan, dan ada yang hampir serupa keduanya. Kemudian seorang amir di Ramlah mengatakan, "Pisahkan yang shahih saja". Kemudian An-Nasa'i menyanring sunannya dan menyalin yang shahih saja dalam sebuah kitab lain yang dinamakan Al-Mujtaba. Kitab ini kedudukannya berada dibawah kitab Shahih Muslim, karena di dalamnya terdapat sedikit hadis dhaif. Lihat, Ibid., 74.

44 Terdapat beragam pendapat yang menyatakan bahwa Al-KutubAl-Sittah atau kitab yang keenam bukanlah kitab Sunan Ibnu Majab melainkan kitab Al-Muwaththa' Imam Malik. Selain itu juga ada yang berpendapat bahwa kitab yang ke enam adalah Sunan AlDarimiy disusun oleh Al-Darimiy. Selain itu juga ada yang berpendapat bahwa kitab yang keenam adalah $\mathrm{Al}$ Muntaqa' disusun oleh Ibn Jarud. Lihat, Jayadi, "Perkembangan Literatur Hadis Pada Masa Awal Islam," 77.

45 Solahuddin and Suryadi, Ulumul Hadis, 43.

46 Kitab Al-Muwathtta' merupakan kitab yang paling tua yang sampai ke tangan kita.Kitab ini ditulis oleh Imam Malik atas perintah Al-Manshur. Dalam pandangan dan perhitungan Al-Abhary, jumlah hadis yang berada dalam al-Muwaththta' baik marfu' maupun
Malik, karena SunanIbnu Majab dinilai lebih rendah dibandingkan kitab-kitab yang lima sebelumnya.

Sistem pembukuan hadis yang dilakukan oleh para ulama hadis pada periode ini adalah:

1. Penghimpun hadis yang memimiliki sifat tercela seperti tidak adil atau daya ingatnya lemah tidak dapat diterima sebagai penghimpun hadis.

2. Tidak menerima hadis yang megandung khurafat atau bertentangan dengan dalil.

Para ulama hadis menghimpun hadis menurut bab-bab, misalnya kitab fiqih, tasawuf, tafsir dan lainnya. ${ }^{47}$

\section{KESIMPULAN}

Pembukuan awal tentang kitab-kitab hadis secara resmi baru dilakukan di masa pemerintahan khalifah Umar bin Abdul Aziz. Pembukuan ini dilakukan atas kekhawatiran Umar bin Abdul Azizi terhadap kehilangan dan ketidak terpeliharanya hadis-hadis Nabi. Beliau khawatir dengan meninggalnya para sahabat di perperangan, menyebarnya para ulama ke berbagai wilayah dan diiringi kewafatan mereka dan munculnya hadis-hadis palsu dari orangorang yang tidak bertanggung jawab, maka dari sini lah khalifah Umar bin Abdul Aziz perlu melakukan pembukan hadis. Perintah pembukuan kitab-kitab hadis ini diperintahkan oleh Umar kepada seluruh pejabat dan para ulama dengan mengirimi surat agar melakukan kodifikasi atau membukukan hadis-hadis Nabi. Surat perintah tentang pembukuan hadis tersebut dikirim khalifah Umar kepada gubernur Madinah, Abu Bakr ibn Muhammad

mauquf ataupun maqthu' ada. 1.726 buah ahdis. Hadis musnad diantaranya berjumlah 600 buah hadis, hadis mursal berjumalh 288buah hadis, hadis mauquf berjumlah 613 buah hadis, dan hadis maqthu' berjumlah 285 buah hadis. Lihat, Ash-Shiddieqy, Sejarah Dan Pengantar Imu Hadis, 77.

47 Ma'shum Zein, Ilmu Memahami Hadis Nabi: Cara Praktis Menguasai Ulumuml Hadits dan Musthalah Hadits (Yogyakarta: LkiS, 2016), 74. 
ibn 'Amr ibn Hasmin. Selain itu Umar juga memerintahkan Zuhri seorang ulama yang ahli fiqih dan hadis di negeri Hijaz dan Syam untuk membukukan hadis melalui surat. Konon katanya Zuhrilah ulama yang awal sekali melakukan pembukuan hadis secara resmi setelah diperintah atau dibolehkan dilakukan pembukuan, terlepas dari sebelumnya sudah ada dilakukan kodifikasi hadis secara individu oleh para ulama. Setelah perintah pembukuan hadis boleh dilakukan secara resmi maka para ulama di saat itu sangat bersemangat melakukan pembukuan.

Selanjutnya pada abad ke II pembukuan hadis dilakukan sangat sistematis. Tidak seperti pembukuan sebelumnya yang hanya dilakukan secara acak dan tanpa melakukan upaya klasifikasi dan sistemasisasi. Namun, di lain sisi ulama yang melakukan pembukuan hadis pada abad ke II dilakukan tanpa penyaringan. Pembukuan hadis yang dilakukan, mencampurkan fatwa-fatwa sahabat dan tabi'in serta hadis Nabi. Sehingg di masa ini kitab-kitab hadis yang ditulis terdapat hadis marfu', mauquf, dan maqthu'. Kompilasi hadis yang ditulis pada periode ini mempunyai judul yang sangat beragam, diantaranya, munatha, mushnaf, jami', sunan, dan musnad. Selain itu para ulama juga menggunakan judul yang lebih khusus seperti jihad, zuhd, maghariy, sirah, dan lainnya. Kitab-kitab hadis di periode ini sangat banyak. Namun kitab yang paling terkenal adalah kitab Al-Muwaththa' karangan Imam Malik, al-Maghaziwal Siyar karangan Muhammad Ibn Ishaq, al-Jami' karangan Abdul Razzaq As-San'any, al-Mushannaf karangan Sy'bah Ibn Hajjaj, al-Mushannaf karangan alLaits Ibn Sa'ad, al-Mushannaf karangan alAuza'i, al-Mushannaf karangan al-Humaidy, alMaghazin Nabawiyah karangan Muhammad Ibn Waqid Al-Aslamy, al-Musnad karangan Abu Hanifah, al-Musnad karangan Zaid Ibn Ali, alMusnad karangan Imam As-Syafi'i dan Muktalif Al-Hadis karangan Imam Asy-Syafi'i.
Selanjutnya transformasi pembukuan hadis di abad ke III mengalami perkembangan yang sangat pesat. Tidak seperti pembukuan hadis sebelumnya yang mengumpulkan hadis dan melakukan pembukuan hadis tanpa memisahkan antara pendapat-pendapat sahabat, fatwa-fatwa tabi'in dengan hadis Nabi. Di abad ke III kedaan seperti itulah yang diperbaiki oleh para ulama. Mereka memisahkan pendapat-pendapat para sahabat, fatwa-fatwa tabi'in dengan hadis Nabi. Lalu di masa ini mereka melakukan penyaringan terhadap hadis, penyaringan hadis terhadap hadis yang bukan dari hadis Nabi atau yang disebut dengan hadis palsu. Lebih uniknya lagi jika dibandingkan dengan periode sebelumnya, di periode ini para ulama melakukan pembukuan hadis dengan mencari hadis-hadis Nabi ke berbagai kota-kota lain. Pencetus mencari hadis Nabi ke berbagai kota dilakukan oleh Imam Bukhari. Usaha yang dilakukan oleh Bukhari berlangsung selama 16 tahun untuk membukukan kitab shahihnya. Kemudian usaha dari Bukhari dilanjutkan oleg muridnya yaitu Muslim dan begitu seterusnya. Sehingga di periode ini terdapat hadis-hadis shahih yang sampai saat ini kita kenal diantaranya adalah Kitab Shahih Bukhari, Kitab Shahih Muslim, Kitab Sunan Abu Dawud, Kitab Sunan AtTirmidzi, Kitab Sunan An-Nasa'iy, Kitab Sunan Ibnu Majah. 


\section{DAFTAR KEPUSTAKAAN}

Ali, Muhammad. “TEORI KLASIFIKASI KITAB HADIS.” Tabdis: Jumal Kajian Ilmu Hadis 8, no. 2 (2019).

Ash-Shiddieqy, Teungku Muhammad Hasbi. Sejarah Dan Pengantar Ilmu Hadis. Semarang: Pustaka Rizki Putra, 2009.

Damanik, Agusman. "URGENSI STUDI HADIS DI UIN SUMATERA UTARA." SHAHIH (Jurnal Kewahyuan Islam) 1, no. 1 (2018).

Farah, Naila. "Mengenal Kitab-Kitab Hadis." Diya Al-Afkar: Jurnal Studi al-Quran Dan al-Hadis 2, no. 01 (2014).

Hading, Hading. "Sejarah Pertumbuhan Dan Perkembangan Hadis." Shaut al Arabiyyah 4, no. 2 (2016): 29-42.

Idri. Studi hadis. Jakarta: Kencana Prenada Media Group, 2010.

Irham, Masturi. "Sistematika Kodifikasi Hadis Nabi Dari Tinjauan Sejarah." Addin 7, no. 2 (2013): 54323.

Jayadi, M. "Perkembangan Literatur Hadis Pada Masa Awal Islam." Khizanah Al-Hikmah: Jurnal Ilmu Perpustakaan, Informasi, Dan Kearsipan 3, no. 1 (2015): 65-78.

Maulana, Luthfi. "Periodesasi Perkembangan Studi Hadits (Dari Tradisi Lisan/Tulisan Hingga Berbasis Digital).” ESENSLA: Jurnal Ilmu-Imu Ushuluddin 17, no. 1 (2016): 111-23.

Octoberinsyah, and kawan-kawan. Al-Hadis. Yogyakarta: Pokja Akademik UIN Sunan Kalijaga, 2005.

Qudsy, Saifuddin Zuhri. "Umar Bin Abdul Aziz Dan Semangat Penulisan Hadis." ESENSLA: Jurnal Ilmu-Ilmu Ushuluddin 14, no. 2 (2013): 257-76.

Saifuddin. Arus TradisiTadwin Hadis dan Historisgrafi Islam. Yogyakarta: Pustaka Pelajar, 2011.

Santosa, Sandi. "Melacak Jejak Pensyarahan Kitab Hadisll." Diroyah: Jurnal Ilmu Hadis 1, no. 1 (2016).

Solahuddin, Agus, and Agus Suryadi. Ulumul Hadis. Bandung: Pustaka Setia, 2009.

Sumbullah, Ummi. Studi 9 Kitab Hadis Sunni. Malang: UIN Malik Press, 2013.

Suparta, Munazier. Ilmu Hadis. Jakarta: Rajawali Pers, 2011.

Suryadilaga, Muhammad Alfatih. Aplikasi Penelitian Hadis Dari Teks ke Kontes. Yogyakarta: Kalimedia, 2016.

Suryadilaga, Muhammad Alfatih, and kawan-kawan. Ulumul Hadis. Yogyakarta: Kalimedia, 2015.

Yusran, Yusran. "KODIFIKASI HADIS SEJAK MASA AWAL ISLAM HINGGA TERBITNYA KITAB AL-MUWATTHA'." Tabdis: Jurnal Kajian Ilmu Hadis 8, no. 2 (2019).

Yusuf, Ismail. "SEJARAH PERKEMBANGAN HADIS DAN METODOLOGINYA PADA ABAD III HIJRIAH." AL ASAS 1, no. 2 (2018): 102-12.

Zain, Lukman. "Sejarah Hadis Pada Masa Permulaan Dan Penghimpunannya." Diya Al-Afkar: Jurnal Studi al-Quran Dan al-Hadis 2, no. 01 (2014).

Zein, Ma'shum. Ilmu Memahami Hadis Nabi: Cara Praktis Menguasai Ulumuml Hadits dan Musthalah Hadits. Yogyakarta: LkiS, 2016. 